8. No treatment of syphilis should be given as a mere routine, but each single case must be considered by itself and treated accordingly.

9. Retention of bismuth in the organism depends on two different factors. Diffuse storage in the different organs of the body is a matter of slight significance; it amounts to scarcely more than $100-150 \mathrm{mg}$. after an intensive course. ${ }^{9}$ The unabsorbed deposits, however, may contain unlimited quantities of bismuth, especially in the case of compounds that are absorbed slowly. This second factor is an important but rather capricious and slightly dangerous item in intermittent syphilis treatment.

10. To avoid an intravascular injection taking the place of an intramuscular it is recommended not only to make an aspiration but also to retract the needle slightly during the injection.

1 Levaditi : Le bismuth dans le traitement de la Syphilis. 1924. Levaditi et alii : Annales de l'Institut Pasteur, vol. 60, 1926, p. 566. ${ }_{4}^{3}$ Levaditi and Nicolau : Ibid., vol. $28,1927, p_{1} 179$.

Idem. Ann de Derm et de Syph., 1925, serie 6 T 6, p. 170, 250.

6 Idem : Brit. Journ. Ven. Dis., vol. 1, No. 1, 1925.

7 Idem: Biochemische Zeitschrift, vol. 198, p. 98.

Idem: Handbuch der Haut u. Geschlechtskrankh., Bd. 18, 1928, p. 234. Idem Arch. of Derm. and Syph., July, 1929.

Biro Istvan: Magyar Orvosi Arch., Bd. 26, 1925, p. 335

Levy and Selter: Arch. f. Kinderheilk., Bd. 75, 1925, p. 281

ruhzit, Tendick, and Sultzaberger: Amer. Journ. of Syph., vol. 11, 1926, p. 87.

Gruhzit and Sultzaberger : Ibid., p 103

p. 89,14 p. $109^{15}$, p. 121.16
ing

17 Kürthy, Biochem. Zeit., vol. 76,1923 , p. 299.

18 Sei and Weise: Arch. f. Schiff s- u. Tropen-hygione, vol. 29, 1925, p. 557.

10 Klauder: Arch. of Derm. and Syph., vol. 7, 1923, p. 721.

29 Oelze: Klin. Woch., vol. 3, 1924, p. 883.
21 Giemsa: Med. Klinik, No. 2, 1926.

12. Gérard and Daunic: Compt. rend. de la Sorićté frane de Biologic, 1897.

24 Jeanselme

25 Sea : Derm : Bull. de la Société franc.

26 Giemsa : Ibid., vol. 79, 1924 , 1923, p.

27 Levy-Bing, Belgodère, and Auclair: Ann. des malad. vénér., 1922, p. 887.

28 Kolle: Med. Klinik, vol. 20, 1924, p. 1097.

29 Beinhauer and Jacob: Amer. Journ. of Syph., vol. 9, 1925, p. 213.

3o Sonnenberg : Przeglad dermatel., vol. 20, 1925 , p. 177 .

31 Cole, Farmer, and Miskdijan: Arch. of Derm. and Syph., vol. 13,

32 Oettinger, Wingate, Todd, and Sollmann: Journ. of Pharmacol. and Exper. Therap., vol. 32, 1927, p. 67.

33 Müller : Münch. med. Woch., vol. 69, 1922, p. 1659

31 Jaffe : Mcd. Klinik, vol. 20, p. 1135.

${ }_{38}$ Gruhzit: Arch. of Derm. and Syph., vol. 13. 1926, p. 195.

37 Akamatsu : Arch. fol. Derm. u. Syph., vol. 155, 1928, p.

${ }^{37}$ Levaditi : Bull. de la Socićté franç. de Derm. et de Syph., 1928, p. 587.

${ }^{39}$ Fournier, Guénot, Schwartz, Yovanovitch: Ibid., 1928, p. 602.

4t Grumach : Derm. Zeit., vol. 49, 1927, p. 328 .

11 Bruck, C. : Ibid., vol. 43, 1925, p 178.

42 Jörgen Munck : Derin. Woch., vol. 84, 1927, p. 367

43 Prater : Ibid., vol. 76, 1923, p. 299.

\section{ETHYLENE ANAESTHESIA.*}

H. P. FAIRLIE, M.D.,

ANAESTHETIST, GLASGOW WESTERA INFIRMARY, AND THE ROYAL HOSPITAL FOR SICK CHILDREN.

Ethylenx gas is administered as an anaesthetic along with oxygen, the proportions of the two gases in the mixture being to some extent variable. Usually the most suitable mixture contains about 88 per cent. of ethylene, 12 per cent. of oxygen; but anything from 10 up to 25 per cent. of oxygen may be found necessary. This variability depends on a number of factors-for example, the age and build of the patient, the condition of the heart and lungs, the nature of the operation, etc. In all administrations the oxygen percentage must be maintained at such a level as will prevent respiratory failure. More than a slight degree of cyanosis is not allowable, and should be regarded as a warning of impending danger. With due regard to this the anaesthesia is a safe one, trouble arising primarily from failure of respiration and corresponding to "bluo collapse"-not the "white collapse" which originates from sudden heart failure. The corrective for "blue collapse" with ethylene is the same as with other anaesthetics-namely, an increase in the proportion of oxygen up to 50,75 , or even 100 per cent. until cyanosis disappears. * Read in the Section of Anaesthetics at the Annual Meeting of the
British Medical Association, Manchester, 1928.
I always employ rebreathing. The administration, therefore, closely resembles that of nitrous oxide and oxygen, and the same apparatus serves very well for both gases. The principal difference lies in the slightly higher percentage of oxygen when ethylene is the anaesthetic, and the resulting absence of, or lesser degree of, cyanosis.

The question very naturally arises, Do we gain anything by using ethylene which nitrous oxide cannot give us? I think that in Great Britain, judging from the scanty references to ethylene, this has been answered for the most part in the negative, and there are undoubtedly grounds for this attitude. At the same time I feel that my answer to the question would be affirmative and that ethylene is finding a definite place among the anaesthetics which I regularly employ. In many respects the results obtained closely resemble those obtained by nitrous oxide and oxygen-for example, safety, rapid action, rapid excretion, and relative immunity from unpleasant aftereffects.

There are two decided points of difference between the two gases, one favourable, the other unfavourable, to ethylene. The first difference is the more profound type of anaesthesia which ethylene develops. I have repeatedly had this clearly demonstrated. An anaesthesia which just failed to achieve the desired depth with nitrous oxideoxygen would become quite satisfactory with ethyleneoxygen. True, in such cases the alternative is offered of supplementing nitrous oxide with ether, but the immunity from unpleasant sequels is then to a greater extent limited. In all cases where I expect a considerable demand as regards depth of anaesthesia $I$ prefer to commence with ethylene. Even then if ether has to be added a smaller quantity suffices than if nitrous oxide had been used. Herein, thon, lies the chief suyeriority of ethylene over nitrous oxide-the more profound narcosis which it produces. It is thereby rendered sufficient for a wider range of operations. It is quite adequate alone for some laparotomies, and for more with the minimum admixture of ether. 'The second difference, and the one in which ethylene compares unfavourably, rests on one of its physical properties. Ethylene gas, as ordinarily obtainable, possesses a very unpleasant odour. Fortunately, this property is practically without effect on the patient, but for the other inhabitants of the operating theatre it presents a serious objection. I can only suggest in mitigation the flavouring of the gas with oil of eucalyptus, which renders it more bearable.

In order to review the scope and usefulness of ethylene in a general way, I propose to regard it from three viewpoints: (1) the patient's; (2) the surgeon's; (3) the anaesthetist's.

\section{The Patient's Point of View.}

The patient's chief interest in his anaesthetic is centred in his experiences " going under" "and " coming out." I ought to remark here that I rarely employ ethylene without a preliminary dose of morphine and hyoscine. The reaction to the taking of the anaesthetic is therefore modified by this preliminary narcotic. I regard the addition of hyoscine as valuable not only in allaying nervousness and inducing a drowsy condition favourable to the induction of anaesthesia, but also for its action on the memory. Many patients, especially the elderly, after a dose of hyoscine, have only hazy recollections, or none at all, of being moved from bed to the theatre. Very often there is a more or less complete blank lasting some little time after their return to bed. But even in the absence of preliminary medication the taking of ethylene does not give rise to the disagreeable sensations which one would expect. I have repeatedly questioned patients about their sensations, and not one has made any reference to the peculiar smell. By taking the gas in full, or nearly full, strength the smell appears to be unnoticed. Consciousness is rapidly abolished, and usually without evidence of resentment or excitement. As regards the "coming out" stage, again the sensations appear to be not unpleasant. Vomiting occurs fairly frequently (in about 75 per cent.), but as a rule within a minute or two of the end of the administration and before consciousness has returned. Thereafter there is seldom any more, though 
in occasional cases nausea and vomiting persist for a time, even up to twenty-four hours. There is no unpleasant tasto or smell lingering.

On questioning a medical man to whom I recently administered ethylene for an appendix operation and colopexy his criticism was that "the experience was not at all unpleasant either going under or coming out."

\section{The S'urgeon's Point of View.}

From the surgeon's viewpoint several factors come into play, depending largely on the trpe of operation. The principal criticisms are directed towards insufficient relaxation and hacmorrhage. In operations where neither of these is of serious noment the anacsthesia meets most requirements.

\section{The Anaesthetist's Point of View.}

Lastly, the anaesthetist, though dealing with an anaesthetic which requires an elaborate apparatus, and an anaesthesia denanding experience and constant watchfulness to maintain within its rather narrow margins, is working within fairly wide limits of safety. In the asphyxial stage which develops when too littlo oxygen is allowed respiratory failure definitely precedes cardiac failure. Ample warning is therefore given by the dark colour of the blood. If this be observed early, and dealt with immediately by an adequate increase in the oxygen content, it is rare that any further steps are necessary.
In an experience extending to over a thousand administrations I have only seen six instances of serious respiratory collapse with cessation of brcathing. In four of these by administering pure oxygen under positive pressure, very easily carried out with McKesson's apparatus, a return of breathing was quickly obtained. In the other two cases this had to be supplemented for brief periods by rhythmic chest compression.

There is one other physical property of ethylene besides its odour to which reference must bo made. It is very inflammable, and in mixtures with air or oxygen may readily be ignited and even exploded. In the United States cases of explosion have been recorded. So far as I am aware none has happened in this country. Tho nature of the hospital buildings and the drier atmosphere of the States probably combine to promote conditions more favourable to this occurrence. I think that, in this country, it is sufficient to remember that ethylene must not be administered in any room where there is an open fire or naked light, nor in any case where cautery or diathermy is to be used.

I have attempted briefly to outline the scope and limitations of ethylene as an anaesthetic. To those who aro familiar with nitrous oxide and oxygen it presents no difficulties, and is well worth a trial. I personally should now regret not having it available for many cases in which I think it is the best anaesthetic.

\section{ERYTHRAEMIA WITH A HIGH DEGREE OF ACHOLURIC JAUNDICE: \\ PROB.ABIY A MANIFESTATION OF COMPENSATORY " HY PERSPJENISU."}

\author{
$\mathrm{BY}$
}

F. PARKES WEBER, M.D., F.R.C.P.,

SENIOR PHYSICIAN TO THE GERMAN HOSPITAL, LONDON.

Sone excess of urobilin in the urine has not rarely been observed in patients suffering from erythraemia (splenomegalic polycythacmia). Lommel, and $\mathrm{L}_{\text {öw }}$ and Popper, found the total excretion of urobilin and urobilinogen above the average, and the blood bilirubin may be in excess, but it is very rarely sufficiently so to give rise to actual (acholuric) jaundice. I have never myself seen or heard of the occurrence in lingland of another case of jaundiced erythraemia* like that of the present patient, whom I first saw in April, 1929, by the kindness of $\mathrm{Dr}$. S. S. Chesser. She then showed, as she still (October 17th, 1929) does, considerable jaundice, without bilirubin in the urine (acholuric jaundice), but with a very highly positive indirect Hijmans van den Bergh reaction in the blood plasma-that is to say, for "blood bilirubin" (which, by the by, I believe to be the same as Virchow's "hacmatoidin").

The patient, $\uparrow$ a Welsh woman, marricel, aged 40 years, living near London, has a typical "erythracmic" appearance and is markedly jaundiced (examined in April and May and October, 1929). Height $152.4 \mathrm{~cm}$.; weight 71.6 kilograms in May, and about $1 \frac{1}{2}$ kilograms more in October, 1929. There is decided excess of subcutancous fat over the thighs, butlocks, and abdomen. Examination of the thorax shows nothing special, excepting (by $x$ rays) rather excessive bronchial markings and very slight enlargement of the aortic arch.

The spleen is enlarged and feels rather firm, the lower edge reaching three fingerbreadths below the costal margin. The liver (not abnormally hard) can be palpated three and a half fingerbreadths below the ribs in the right nipple line. No ascites. No subcutaneous oedema. Menstruation regular. Bowels not confined. Brachial blood pressure $165 / 95 \mathrm{~mm}$. Hg. Urine (October 17th) : specitic gravity 1011; clear; rather high yellow; acid; a little albumin (moderate "cloud" on boiling); no sugar; excess of urobilin and urobilinogen; no bilirubin; excess of indican; one or two hyaline tube casts seen in the centrifuge scdiment. Ophthalmoscopic examination shows a typically "erythraemic fundus." Basal metabolism (two estimations), 127 per cent.

* For references to the literature on the association of erythraemia with jaundice and also with hepatic cirrhosis sec Wcber and Bode, Polycythaemia, etc., Iondon, $1929,1 \mathrm{p}, 13$.

t The case was remonstrated, but not exactly described, at the meeting of the Clinical Section of the Royal Society of Medicine on November 8th,
1929 .
Blood count (April 29th) : haemoglobin 120 per cent.; erythrocytes, 7,880,000 per c.mm. of blood; colour index $=0.76$; white cells 16,350 (polymorphonuclears 70 per cent., basophils 3 per cent., eosinophils 3 per cent., lymphocytes 21 per cent., monocytes 3 per cent.); no nucleated or abnormal red cells seen. Thrombocytes: 1,512,960 per c.mm. of blood. The blood serum gives an extremely strong positive indirect Hijmans van den Bergh reaction for "blood bilirubin." The resistance of the washed erythrocytes towards graduated hypotonic sodium chloride solutions seems to be within normal limits, haemolysis commencing with the 0.5 per cent. solution and becoming complete with the 0.32 per cent. solution. The blood serum gives negative Wassermann and Meinicke reactions. Dr. T. C. Hunt kindly estimated the cholesterol in the blood serum by the Autenrieth colorimetric method (as described by L. Pincussen, Mikromethodik, fourth edition, Leipzig, 1928 , p. 143), and found it to be $190 \mathrm{mg}$. pe 100 c.cm. A recent blood count (October 17th) showed decided increase in the polycythaemia : hacmoglobin 125 per cent.; crythrocytes $8,900,000$; colour index $=0.7$; white cells 18,650 . The erythrocyte count still more recently (November 7 th) was $10,100,000$.

The patient was married at 21 years of age and has had three children (all living and healthy); no miscarriages. There is nothing special in her family history. She is said to have had typhoid fever in childhood. Her first attack of jaundice was eight or nine years ago, and since then she has had many icteric exacerbations, but of late seems never to have become quite free from jaundice. She began to suffer from vertigo twelve years ago and the giddiness is worse during the exacerbations of jaundice. The attacks of giddiness come on especially when she is walking in the open air, and during a recent attack she fell and cut her forehead (October 15th). For a long time she has been subject to occasional attacks of pain in the left lumbar region, passing down the outer part of the left thigh, but she has had no attack suggesting biliary colic. She suffers from occasional epistaxis and often has severe headaches. It was five years ago that she first noticed that her face had become redder and that she flushed very easily. She has been relieved by blood-letting, and this is to be carried out again. It is certain that her jaundice varies much in degree. In fact, at times there is no obvious jaundice.

\section{Remarks.}

It secms probable that the chronic acholuric jaundice and the icteric exacerbations in the present case are due to active destruction of the erythrocytes in tho spleen (and possibly in other parts of the reticulo-endothelial system), but there is no evidence of abnormal "fragility" of the red cells. Tho jamndice might therefore be interpreted as the manifestation of a spontancous attempt to compensate for the excessive production of erythrocytes in the bone marrow by increased haemolysis in the spleen-a compensatory form of "hypersplenism." * Periodic bloodletting would seem to bo the safest treatment. in such a

* If this is so an increase in the degrec of jaundice should be accompanied by a decrease in the crythrocyte count. On one occasion we her erythroeyte count. 